\title{
A védelmi felelősség koncepciója, avagy van-e új a nap alatt?
}

\author{
Védelmi felelösség - nemzetközi büncselekmények - \\ humanitárius intervenció - felelősség
}

A nemzetközi kapcsolatok és jog berkeiben egyre gyakrabban hallani a „responsibility to protect", magyarul védelmi felelősség koncepciójáról, akár megváltásként emlegetve, akár jogi tartalom nélküli szlogenként aposztrofálva. Idegen nyelvű tanulmányok tömege dicséri vagy éppen kritizálja, ${ }^{1}$ ezzel szemben a magyar szakirodalom eddig kevéssé foglalkozott a témával.

A 2000-es évek elején először egy tanulmányban jelent meg a „védelmi felelősség” kifejezés, amely röviden azt takarta, hogy az államnak kötelessége megvédeni a lakosságát a súlyos emberi jogi jogsértésektöl, és ezen kötelességének elmulasztása során nem bújhat a szuverenitás elve mögé. ${ }^{2}$ Az ENSZ 2005. évi csúcstalálkozóján (2005 World Summit) a nemzetközi közösség „kijelentette és elfogadta”, hogy az állam köteles megvédeni a lakosságát a népirtástól, etnikai tisztogatástól, emberiesség elleni bűncselekményektöl és háborús bủncselekményektől (tehát védelmi fele-

* Dr. Szalai Anikó egyetemi adjunktus, Szegedi Tudományegyetem Állam- és Jogtudományi Kar, Nemzetközi Jogi és Európa-jogi Tanszék. E-mail: szalaianiko@juris.u-szeged.hu.

1 Lásd pl.: Mohamed, Saira: Taking Stock of the Responsibility to Protect, Stanford Journal of International Law, Vol. 48 (Summer 2012) Issue 2, 319-340; Evans, Gareth: End of the Argument: How We Won the Debate Over Stopping Genocide, Foreign Policy, Dec. 2011. http://www.foreignpolicy.com/articles/2011/11/28/ gareth_evans_end_of_the_argument (2013. 03. 20.); PATRICK, Stewart: Libya and the Future of Humanitarian Intervention, Foreign Affairs, Aug. 26, 2011. http://www.foreignaffairs.com/articles/68233/stewart-patrick/ libya-and-the-future-of-humanitarian-intervention?page=show (2013. 03. 20.); StRAuss, Ekkehard: A Bird in the Hand is Worth Two in the Bush - On the Assumed Legal Nature of the Responsibility to Protect, Global Responsibility to Protect, 1 (2009) 291-323; Hannum, Hurst: The Responsibility to Protect: Paradigm or Pastiche, Northern Ireland Legal Quarterly, Vol. 60 (2009) Issue 2, 135-146; WHEELER, Nicholas J.: A Victory for Common Humanity - The Responsibility to Protect after the 2005 World Summit, Journal of International Law and International Relations, Vol. 2 (Winter 2005) Issue 1, 95-106; FocARelLI, Carlo: The Responsibility to Protect Doctrine and Humanitarian Intervention: Too Many Ambiguities for a Working Doctrine, Journal of Conflict \& Security Law, Vol. 13 (2008) Issue 2, 191-214; RoBERTSON, Sue: Beseeching Dominance: Critical Thoughts on the Responsibility to Protect Doctrine, Australian International Law Journal, Vol. 12 (2005) 33-56.

2 International Commission on Intervention and State Sovereignty: The Responsibility to Protect, Canada, 2001. http://responsibilitytoprotect.org/ICISS\%20Report.pdf (2013. 03. 20.). 
lőssége van). ${ }^{3} \mathrm{Az}$ ENSZ-közgyülés 2009-ben napirendre vette a koncepció tárgyalását, ${ }^{4}$ az ENSZ-fótitkár azóta minden évben jelentést készített a témáról. ${ }^{5}$

\section{A koncepció elemei}

Az ENSZ-főtitkár jelentései alapján a védelmi felelősség koncepciója 3 elemből, pillérböl épül fel:

1. Elsődlegesen az állam felelőssége a lakosság megvédése a népirtástól, etnikai tisztogatástól, emberiesség elleni bủncselekményektől és háborús bủncselekményektöl.

2. A nemzetközi közösség köteles bátorítani és segíteni az államokat annak érdekében, hogy teljesíteni tudják a védelmi felelösségüket/kötelezettségüket.

3. Amennyiben egy állam nem teljesíti a védelmi kötelességét, úgy a nemzetközi közösség felelőssége a lakosság megvédése az 1 . pontban említett büncselekményektől. A nemzetközi közösség bármilyen megfelelö eszközt alkalmazhat ehhez, és fel kell készülnie arra, hogy kollektíven cselekedjen ennek érdekében.

A fötitkári jelentések részletezik is, hogy az egyes pilléreket hogyan kell értelmezni, végrehajtani. Az első pillér alapján az államoknak minél több emberi jogi és humanitárius jogi egyezményben kellene részes féllé válniuk, és azokat megfelelöen átültetniük, alkalmazniuk kellene a belső jogukban is. Segíteniük kellene az ENSZ Emberi Jogi Tanácsának munkáját, véget kellene vetni az ilyen büncselekményeket elkövető személyek büntetlenségének, elő kellene segíteniük az egyéni büntetőjogi felelősségre vonást, az oktatás és képzések során hangsúlyt kellene fektetniük az emberi és humanitárius jog terjesztésére, valamint párbeszédet kezdeményezni a társadalom egyes csoportjai között. Az állam köteles a nevezett büncselekmények elkövetését megelőzni, ha az elkövetés megkezdődött, akkor megállítani és az elkövetőket felelősségre vonni. ${ }^{6}$

A második pillérbe tartozik mindenféle nemzetközi segítség, kapacitásépítés, párbeszéd, oktatás, képzés, az emberi jogi és humanitárius jogi sztenderdek terjesztése, a preventív diplomácia és a békefenntartók küldése a helyzet romlásának megelözése érdekében. ${ }^{7}$

3 A/60/1 (2005) 2005 World Summit Outcome, 138-139. pontok. "Each individual State has the responsibility to protect its populations from genocide, war crimes, ethnic cleansing and crimes against humanity. This responsibility entails the prevention of such crimes, including their incitement, through appropriate and necessary means. We accept that responsibility and will act in accordance with it."

4 A/63/308 (2009) The responsibility to protect.

5 A/63/677 (2009) Implementing the responsibility to protect: report of the Secretary-General; A/64/864 (2010): Early warning, assessment and the responsibility to protect: report of the Secretary-General; A/65/877S/2011/393 (2011): The role of regional and subregional arrangements in implementing the responsibility to protect: report of the Secretary-General; A/66/874-S/2012/578 (2012) Responsibility to protect: timely and decisive response: report of the Secretary-General.

6 A/63/677 (2009) Implementing the responsibility to protect: report of the Secretary-General, 16-17., 19., 21., 25., 27. pontok.

7 A/63/677 (2009) Implementing the responsibility to protect: report of the Secretary-General, 33., 41-43. pontok 
A harmadik pillér a nemzetközi kollektív cselekvést takarja, nevezetesen „bármilyen megfelelő eszköz" alkalmazását, a diplomáciai vitarendezési eszközöktől kezdve a gazdasági szankciókon át a katonai beavatkozásig - természetesen az ENSZ Alapokmány szabályaira tekintettel. ${ }^{8}$

A felelősség tehát átfogja mind a megelőzési, mind a megakadályozási kötelezettséget. Ezek a pillérek összefüggnek, általában nem választható el élesen a megelőzés és a válasz. A felelősség elsődlegesen az államot terheli, azonban azzal szinte egyenrangú kötelezett a nemzetközi közösség is. A pillérek alapján foganatosítandó cselekmény mindig az adott eset jellemzőitől függ, nem feltétlenül kell sorrendben alkalmazni őket. ${ }^{9}$

\section{A koncepció szükségessége}

A védelmi felelősség koncepciójának támogatói szerint annak szükségességét a 20. század brutális tapasztalatai támasztják alá, a holokauszttól kezdve a kambodzsai, ruandai és srebrenicai mészárlásig. Annak ellenére, hogy már az 1940-es évek második felében több nemzetközi dokumentumban is megfogalmazták az alapvető emberi jogok tiszteletben tartását (1945. évi ENSZ Alapokmány, az 1948. évi Emberi Jog Egyetemes Nyilatkozata és a Népirtás tilalmáról szóló egyezmény, az 1949. évi genfi egyezmények), még évtizedekkel később is látunk példákat azok súlyos megszegésére. Ráadásul ezeket az egyezményeket az elfogadásuk után évtizedekig hagyták „porosodni”, megsértésükért nem történt felelősségre vonás, így a rendelkezéseik értelmezése is nagyrészt elmaradt.

A konfliktusok természete megváltozott, jellemzőbbek az államon belüli összeütközések, amelyek tipikus célpontja a civil lakosság. A háborús, emberiesség elleni büncselekményekre, népirtásra gyakran az állam részvételével kerül sor, amely nem akarja vagy nem tudja megakadályozni az ilyen cselekményeket, sőt akár tevékenyen részt vesz az elkövetésükben. A népirtásra, etnikai tisztogatásra nem váratlanul, egyik napról a másikra kerül sor tipikusan, hanem hosszú folyamat eredményeként. Ha jobban odafigyelne a nemzetközi közösség a jelekre, akkor az ilyen súlyos társadalmi konfliktusok megakadályozhatóak lennének. ${ }^{10}$

A koncepció kialakulásának közvetlen előzményeként az 1999. évi kosovói beavatkozás említhető, amelyet az ENSZ Biztonsági Tanács nem engedélyezett, azonban az európai és észak-amerikai államok jelentős többsége szükségesnek ítélt meg azért, hogy ne történhessenek a boszniai jogsértésekhez hasonlóak. Az 1990-es években súlyos bírálat érte az ENSZ-t azért, mert nem akadályozta meg a ruandai

8 Uo. 49-59., 62., 64. pontok.

9 Lásd pl.: A/66/874-S/2012/578 (2012): Responsibility to protect: timely and decisive response: report of the Secretary-General.

10 Panel discussion on the occasion of the tenth anniversary of the Rwanda genocide - "A Decade After Rwanda: The United Nations and the Responsibility to Protect" (7 April 2004) - Webcast: http://webcast. un.org/ramgen/specialevents/sg040407rwanda.rm (2013. 03. 20.); Interactive Thematic Dialogue of the United Nations General Assembly on the Responsibility to Protect, 23 July 2009, United Nations Headquarters http://www.un.org/ga/president/63/interactive/responsibilitytoprotect.shtml (2013. 03. 20.). 
népirtást, viszont bőséges kritikát kaptak a humanitárius intervenciók is, akár BTfelhatalmazással (pl. Boszniában), akár anélkül történtek (pl. Kosovóban). Ezen kettősség kiküszöbölése érdekében kezdtek mind tudományos körökben, mind az ENSZben foglalkozni a védelmi felelősséggel. ${ }^{11}$

A védelmi felelősség alkalmazásától az ENSZ-főtitkár azt várja, hogy az államok egyre inkább képesek legyenek saját maguk megadni a védelmet, így a nemzetközi közösség beavatkozására (a 3. pillér alapján) egyre kevésbé legyen szükség. ${ }^{12}$

\section{A koncepció nemzetközi jogi alapjai}

Érdekes módon a védelmi felelősséget kidolgozó szakértői jelentés és az ENSZfötitkári jelentések igen hanyagul kezelik a koncepció jogi alapjait, amiből első ránézésre arra következtethet az olvasó, hogy a három pillérben megfogalmazottaknak nincs is jogi háttere, azok pusztán politikai kinyilatkoztatások. Ez távol áll az igazságtól.

\subsection{Az első pillér}

Az első pillér tekintetében az állam kötelességét nemzetközi egyezmények sora és a szokásjog alapozza meg. Az első pillér alapján a fő kötelezettségek (1) a jogsértések megelőzése, (2) a megkezdett jogsértések megállítása és (3) az elkövetők felelősségre vonása. Véleményem szerint az első pillér kifejezetten arra az államra utal, amelynek a területén a jogsértés megtörténhet vagy megtörténik. A többi állam és a nemzetközi közösség teendőit a másik két pillér tartalmazza. Így tehát az első pillér kapcsán kifejezetten arra kell koncentrálnunk, hogy az állam számára a nemzetközi szerződéses és szokásjog milyen kötelezettségeket ír elő.

A népirtás tilalmáról szóló 1948. évi egyezményben és a humanitárius jog körébe tartozó számos egyezményben (pl.: 1949. évi genfi egyezmények) az államok már évtizedekkel ezelőtt kinyilvánították, hogy az első pillér által átfogott bűncselekmények nemzetközi jogsértések.

Ezen cselekményeket nemcsak a szerződési jog tiltja, hanem a szokásjog is. Ezek a tettek sem háború, sem béke idején nem elfogadhatóak, ahogyan az kitünik az 1966. évi Polgári és Politikai Jogok Nemzetközi Egyezségokmányából is. Ez az emberi jogi egyezmény expressis verbis felsorolja azokat az alapvető emberi jogokat, amelyeket semmilyen körülmények között nem lehet korlátozni (és amelyek megsértése a fent nevezett büncselekmények megvalósulásához vezethet). ${ }^{13}$

A népirtás tilalmáról szóló egyezmény 1. cikke alapján kötelezik magukat az államok arra, hogy „ellene megelőző rendszabályokat foganatosítanak, elkövetését pedig

International Commission on Intervention and State Sovereignty: i. m., Foreword, VII.

12 A/66/874-S/2012/578 (2012): i. m., 5.

13 4. cikk (1). 
megbüntetik". ${ }^{14}$ Ez alapján egyértelmüen kijelenthető, hogy az államok nemcsak maguk kötelesek tartózkodni ilyen cselekmény elkövetésétől, hanem ha a területükön más személyek, csoportok teszik ezt, akkor is kötelesek ellene fellépni. Az állam ilyen fellépése nemcsak az elkövetők büntetőjogi felelősségre vonását jelenti, hanem a cselekmények elkövetésének megakadályozását, sőt a megelőzését is. A három fő kötelesség - tehát a megelőzés, megállítás és felelősségre vonás - közül az utóbbi kettő értelmezése a kevésbé problémás. A jogsértés megakadályozásának vagy megállításának kötelezettsége nem egyedi, nemcsak ezekre a bűncselekményekre vonatkozik, hanem minden nemzetközi jogsértésre. Az ilyen bűnöket elkövető egyének felelősségre vonása évtizedekkel ezelőtt még korántsem volt egyértelmű, ${ }^{15}$ azonban az elmúlt 20 év jogfejlődése efelöl sem hagy kétséget. A nürnbergi és tokiói, majd a jugoszláv, ruandai ad hoc törvényszékek, a hibrid törvényszékek és a Nemzetközi Büntetőbíróság léte is alátámasztja ezt.

A megelőzési kötelezettség értelmezése során azonban nehézségekbe ütközünk. Az 1948. évi, a népirtás megelőzéséről és megbüntetéséről szóló egyezmény már a címében is utal erre az obligációra, igaz, az ezek után várt rendelkezései szűkszavúak. Összesen két helyen említi a megelőzést, először a már idézett 1., majd a 8. cikkben. Az 1. cikkben említett megelőző rendszabályok foganatosítását azzal egészíti ki a 8. cikk, hogy az államok az ENSZ illetékes szerveihez fordulhatnak annak érdekében, hogy azok az ENSZ Alapokmánynak megfelelően olyan rendszabályokat foganatosítsanak, amelyekkel megelőzhetik vagy megszüntethetik a büncselekményeket. Ez utóbbi szakasz valójában nem jelent újdonságot, mivel az ENSZ Alapokmány alapján minden állam jogosult a Biztonsági Tanácshoz fordulni a nemzetközi béke és biztonság veszélybe kerülése esetén. Az 1948. évi egyezményből nem derül ki ennél több az államok megelőzési kötelezettségének tartalmáról. ${ }^{16}$

A megelőzés szó hétköznapi, nyelvtani értelme valami bekövetkezésének a megakadályozása. A Tudományos és Köznyelvi Szavak Magyar Értelmező Szótára szerint a megelőzés jelentése: „A társadalomra veszélyes magatartás megvalósulásának ellenintézkedésekkel történő meggátlása. Akkor kerül végrehajtásra, amikor a büncselekmény még nem valósult meg, de az arra utaló magatartás észlelhető. A büncselekmény elkövetési lehetőségeinek szűkítése, a bűnözés felé sodródó személy bűnös tevékenységének kibontakozását elhárító komplex tevékenység."17 Mindkét meghatározás esetében látható cél, hogy az esemény soha ne következzen be. Noha a második meghatározás inkább csak a speciális prevencióra utal, közismert, hogy

14 1955. évi 16. törvényerejű rendelet a népirtás bűntettének megelőzése és megbüntetése tárgyában 1948. évi december 9. napján kelt nemzetközi egyezmény kihirdetéséről.

15 Lásd pl.: WHITAKER, Benjamin: Revised and updated report on the question of the prevention and punishment of the crime of genocide (the 'Whitaker Report'), United Nations, ECOSOC, UN Doc. No. E/CN.4/ Sub.2/1985/6 (2 July 1985). 71., 76. pontok.

16 Szinte szó szerint azonos rendelkezéseket tartalmaz az apartheid-bűncselekmények leküzdéséről és megbüntetéséről szóló 1973. évi egyezmény, amely utal is a népirtás tilalmáról szóló egyezményre. Lásd 1976. évi 27. törvényerejű rendelet az apartheid-büncselekmények leküzdéséröl és megbüntetéséről szóló, New Yorkban, az Egyesült Nemzetek Szervezete Közgyúlésén, 1973. november 30-án elfogadott nemzetközi egyezmény kihirdetéséröl, preambulum, 4., 6., 8. cikkek.

17 Tudományos és Köznyelvi Szavak Magyar Értelmező Szótára, http://meszotar.hu/keres-megelőzés (2013. 03. 20.). 
a megelőzés általánosságban, generálisan is értendő. A népirtás tilalmáról szóló egyezmény előkészítő irataiban sincs pontosan meghatározva, hogy mit kell megelőzés alatt érteni, de a kontextuális értelmezés segítségével annyi kikövetkeztethető, hogy az államok már akkor kötelesek cselekedni, ha a népirtásra elökészület folyik. ${ }^{18}$ Az egyezmény tiltja mind a felbujtást, mind az elökészületi és kísérleti cselekményeket. ${ }^{19} \mathrm{~A}$ titkársági travaux szerint előkészületi cselekménynek minősül a népirtás technikájának kifejlesztésére vonatkozó tanulmány készítése és kutatás végzése, a népirtásra alkalmazás szándékával építmények, berendezések, bármilyen tárgy vagy anyag létrehozása, készítése, építése, beszerzése, birtoklása, eladása, valamint népirtás elkövetésére felhívás, parancs adása. ${ }^{20}$ Tehát amikor ezeket a cselekményeket tapasztalja egy állam, akkor nyilvánvalóan köteles megelőzni a népirtás megvalósítását. Az azonban továbbra is kérdéses, hogy ennél tágabb értelemben van-e megelőzési kötelezettsége.

A megelözés értelme és nemzetközi jogi kötőereje a Nemzetközi Bíróságot is foglalkoztatta. A Bosznia és Hercegovina kontra Szerbia és Montenegró jogvitában kijelentette a népirtás tilalmáról szóló egyezmény 1. cikkével kapcsolatosan: „...a szerződő feleknek közvetlen kötelezettsége a népirtás megelőzése". ${ }^{21}$ Ez a kötelezettség elkülönül a megbüntetés kötelezettségétöl, és több, mint amit a 8. cikk elöír. Az államokat akkor is terheli, ha az ENSZ szervei is foglalkoznak már az üggyel, ebben az esetben is kötelesek minden tőlük telhetőt megtenni a megelőzés érdekében - betartva a releváns nemzetközi jogot. ${ }^{22} \mathrm{~A}$ bíróság kiemelte, hogy a nemzetközi jogban nincs általános jelentése a megelőzésnek, az államok megelőzési kötelezettségének tartalma egyezményenként változó. ${ }^{23} \mathrm{~A}$ megelőzés nem eredménykötelezettség, tehát a tanúsított magatartás, a „kellö gondossággal” eljárás a lényeg, és nem feltétlenül az eredmény. ${ }^{24} \mathrm{Az}$ egyik fontos szempont a megelőzési kötelezettség kapcsán az, hogy az állam milyen mértékben képes befolyásolni az elkövetők magatartását - ez függ a két állam földrajzi távolságától, a politikai és egyéb kapcsolatuk jellegétől és erősségétöl, a nemzetközi jog által megengedett keretektől. Továbbá a megelőzési kötelezettség elmulasztásáért csak akkor lehet felelősségre vonni egy államot, ha a népirtás már bekövetkezett. A megelőzési kötelezettség kezdete pedig az az időpont, amikor az állam tudomására jut vagy általában elvárhatóan tudomására kellett volna jutnia, hogy a népirtás bekövetkezésének veszélye jelentős. ${ }^{25}$

Míg a népirtás tilalmáról szóló egyezmény a címében és a rendelkezéseiben is tartalmazza a megelőzés kifejezést, addig a többi búncselekmény jogi alapját nyújtó

18 Secretariat Draft - First Draft of the Genocide Convention, Prepared by the UN Secretariat. May, 1947, UN Doc. No. E/447.

19 3. cikk.

20 Secretariat Draft - First Draft of the Genocide Convention, Prepared by the UN Secretariat. May, 1947, UN Doc. No. E/447. Art. II. [Punishable offences].

21 Application of the Convention on the Prevention and Punishment of the Crime of Genocide (Bosnia and Herzegovina v. Serbia and Montenegro), Judgment of February 26, 2007, I.C.J. Reports 2007. 165. pont.

22 Uo. 427. pont.

23 Uo. 429. pont.

24 Uo. 430. pont.

25 Uo. 430-432. pontok. 
más egyezmények, például a genfi egyezmények egyáltalán nem szólnak erről. Ezek körében tehát csak az feltételezhető, hogy esetleg szokásjogként kialakult a megelőzés elvárása.

Megjegyzendő, hogy a népirtás megelőzésének kötelezettsége - az egyezmény alapján - minden államot terhel, mivel azonban az erre vonatkozó részletszabályokat nem tartalmazza, így a harmadik államok cselekvési lehetőségeit és kötelezettségeit a második és harmadik pillérrel összefüggésben tekintem át.

\subsection{A második pillér}

A második pillér a nemzetközi segítségről és együttmüködésről szól, amely szintén nem tekinthető nóvumnak. A népirtás tilalmáról szóló 1948. évi egyezmény preambulumában kifejti, hogy „a népirtás a nemzetközi jogba ütköző és az Egyesült Nemzetek Szervezete szellemének és céljainak ellentmondó büncselekmény és [...] azt a civilizált világ elítéli; [...] az emberiségnek ettől a gyűlöletes csapástól való megmentésére nemzetközi együttműködés szükséges." ${ }^{26}$ Az együttműködési kötelezettség összhangban áll az ENSZ Alapokmány alapelveivel és szellemiségével, például az ENSZ Alapokmány Preambulumában kifejtettekkel: „megmentjük a jövő nemzedékét a háború borzalmaitól [...], hitet teszünk az alapvető emberi jogok [...] mellett”. ${ }^{27}$ Az ENSZ Alapokmány 1. cikkében megfogalmazott célok alapján is a nemzetközi közösség tagjai együttmüködnek a béke érdekében: „Az Egyesült Nemzetek célja, hogy [... a] baráti kapcsolatokat fejlessze és az általános béke megerősítésére alkalmas egyéb intézkedéseket foganatosítson; [... és] nemzetközi együttmüködést létesítsen." ${ }^{28}$ Hasonló együttmüködési kötelezettségvállalást tartalmaz több ENSZ-közgyűlési határozat is. ${ }^{29}$

A Nemzetközi Jogi Bizottság felelősségi tervezete szerint az államok kötelesek együttműködni a nemzetközi jog feltétlen alkalmazást igénylő normáinak súlyos megsértését megakadályozandó - akkor is, ha közvetlenül nem érintettek. ${ }^{30}$ Erre a Nemzetközi Bíróság is felhívta a figyelmet. ${ }^{31} \mathrm{Az}$ államok együttmüködési kötelezettségének szerepe jelentős mind a megelőzés, mind a megállítás és megbüntetés terén.

26 Secretariat Draft - First Draft of the Genocide Convention, Prepared by the UN Secretariat, May, 1947, UN Doc. E/447. Art. II. [Punishable offences].

27 1956. évi I. törvény az Egyesült Nemzetek Alapokmányának törvénybe iktatásáról.

28 Uo.

29 PI.: A/55/2 (2000) United Nations Millennium Declaration; A/66/749 (2012) Delivering justice: programme of action to strengthen the rule of law at the national and international levels; A/66/291 (2011) Strengthening the role of mediation in the peaceful settlement of disputes, conflict prevention and resolution; A/66/254 (2011) Intergovernmental process of the General Assembly on strengthening and enhancing the effective functioning of the human rights treaty body system.

30 Draft Articles on Responsibility of States for Internationally Wrongful Acts with commentaries, Yearbook of the International Law Commission, 2001, vol. II, Part Two. 114.

31 Application of the Convention on the Prevention and Punishment of the Crime of Genocide (Bosnia and Herzegovina v. Serbia and Montenegro), Judgment of February 26, 2007, I.C.J. Reports 2007. $162 ., 165$. pontok. 


\subsection{A harmadik pillér}

A harmadik pillér jogi alapja a legösszetettebb kérdés, amely négy irányból is megközelíthető: (1) az ENSZ Alapokmány, (2) a humanitárius intervenció, (3) a jus cogens normasértésért való felelősség és (4) egyéb, szerződésen vagy szokásjogon alapuló kötelezettség.

Az ENSZ Alapokmány, különösen annak VI., VII. és VIII. fejezete alapján a nemzetközi közösség számos eszközt bevethet a nemzetközi béke és biztonság megörzése, valamint helyreállítása érdekében. Ezen eszközök közül a legkorlátozottabban alkalmazható a katonai beavatkozás, amelyet csak a Biztonsági Tanács rendelhet el. A kérdést tehát úgy kell feltennünk, hogy a népirtás, etnikai tisztogatás, emberiesség elleni bűncselekmények és háborús büncselekmények veszélyeztetik-e a nemzetközi békét és biztonságot. A nemzetközi béke és biztonság jelentése kiszélesedett az elmúlt évtizedekben, és ezekre a cselekményekre ma már vitán felül úgy tekintünk, mint amelyek akadályozzák, veszélyeztetik a békét még akkor is, ha csak egy állam területén követik el azokat. ${ }^{32}$ Természetesen az már más kérdés, hogy a Biztonsági Tanács elrendel-e bármilyen fegyveres kényszerítő intézkedést, de a nemzetközi jog alapján erre kizárólagos joga van.

A humanitárius intervenció a szokásjogban kialakult jogintézmény, amely mögött az emberek védelmének szándéka áll. Noha pontos fogalma nehezen leírható egy mondatban, Sulyok Gábor e témával kapcsolatos műve alapján elmondható, hogy a humanitárius intervenció egy vagy több állam vagy nemzetközi szervezet által végrehajtott fegyveres erőszak egy másik állammal szemben azért, hogy megállítsák az ezen állam által véghezvitt tömeges és súlyos emberi jogi vagy humanitárius jogi jogsértéseket. A beavatkozást a célállam nem kéri, annak ultima ratio jellege van, a beavatkozónak érdektelenül és a nemzetközi jog releváns szabályainak a betartásával kell eljárnia. ${ }^{33}$ Látható, hogy ez jelentősen hasonlít a védelmi felelősség koncepciójához, azonban a jogsértési kör a humanitárius intervenció esetében tágabbnak és kevésbé pontosan definiáltnak tünik, mint a védelmi felelősségnél meghatározottak. A humanitárius intervenció esetében is igaz, hogy jogszerüségi kritérium a Biztonsági Tanács felhatalmazása. Mivel az ENSZ Alapokmány összeütközés esetén minden nemzetközi jogi normával szemben elsöbbséget élvez (103. cikk), így a humanitárius intervenció sem hajtható végre - jogszerüen - e nélkül.

32 Ezt kifejtette az ENSZ több szerve is. Lásd pl. a Biztonsági Tanács határozatai közül: S/RES/1296 (2000) Protection of Civilians in Armed Conflict; S/RES/1318 (2000) Effective role for the Security Council in the maintenance of international peace and security, particularly in Africa; S/RES/1625 (2005) Threats to international peace and security. Az ENSZ-fötitkár jelentései közül pl.: S/1999/957 (1999) Protection of civilians in armed conflicts; A/59/565 (2004) The Secretary-General's High-level Panel Report on Threats, Challenges and Change, A more secure world: our shared responsibility; A/55/985-S/2001/574 (2001) Prevention of Armed Conflict. Az ENSZ-közgyűlés határozatai közül pl.: A/66/150 (2011) Torture and other cruel, inhuman or degrading treatment or punishment; A/96/1 (1946) The Crime of Genocide; A/1761/17 (1962) The policies of apartheid of the Government of the Republic of South Africa; A/2202 A (XXI) (1966) The policies of apartheid of the Government of the Republic of South Africa.

33 Sulyok Gábor: A humanitárius intervenció elmélete és gyakorlata, Gondolat Kiadó, Budapest, 2004, 64-68, 323-329. 
A védelmi felelősség koncepciójánál nevesített bűncselekmények egy része olyan, amelynek tilalma kogens norma. Az elmúlt évtizedek nemzetközi jogi szakirodalma és esetjoga alapján egyértelmü, hogy jus cogens többek között a népirtás tilalma, a kínzás tilalma, a rabszolgaság tilalma. ${ }^{34}$ A Nemzetközi Jogi Bizottság ezek közé sorolja a nemzetközi bủncselekményeket is (tehát a népirtáson kívül a háborús bủnöket és az emberiesség elleni búncselekményt is). ${ }^{35}$ Ha a védelmi felelősség koncepciójában említett nemzetközi büncselekmények, vagy legalább a legsúlyosabb formájuk tilalmát jus cogensnek tekintjük, akkor ennek megsértése erga omnes felelösséget keletkeztet. $^{36}$

A Nemzetközi Jogi Bizottság által készített, az államok nemzetközi jogsértésért való felelősségéről szóló tervezete szerint az államok kötelesek együttműködni avégett, hogy az általános nemzetközi jog feltétlen alkalmazást igénylő szabályaiból eredő kötelezettség állam általi súlyos megszegésének jogszerű eszközökkel véget vessenek. ${ }^{37}$ A jus cogenst sértő állam felelősségére bármely állam jogosult hivatkozni, mivel a megszegett kötelezettség a nemzetközi közösség egészének irányában áll fenn. ${ }^{38} \mathrm{Ez}$ azt is jelenti, hogy bármely állam alkalmazhat ellenintézkedést ilyen esetben, tehát nemzetközi jogsértéssel próbálhatja rákényszeríteni a jogszerű magatartásra az államot - amely azért nem lesz jogsértés, mert válaszcselekmény a korábbi jogsértésre. Az ellenintézkedés végrehajtásának számos feltétele van, amelyek közül témánk szempontjából a legfontosabb, hogy „az ellenintézkedések nem érinthetik:

a) az erőszakkal való fenyegetéstől vagy az erőszak alkalmazásától való tartózkodás kötelezettségét, az ENSZ Alapokmányában foglaltak szerint;

b) az alapvető emberi jogok védelmére irányuló kötelezettségeket;

c) a represszáliát tiltó humanitárius jellegü kötelezettségeket;

d) az általános nemzetközi jog feltétlen alkalmazást igénylő szabályaiból fakadó más kötelezettségeket."39

Tehát a nemzetközi közösség tagjai alkalmazhatnak gazdasági szankciókat, embargót, de az erőszakos ellenintézkedésre továbbra is csak a Biztonsági Tanács jogosult.

Az előző három variáció mellett vannak bizonyos nemzetközi szerződések, amelyek minden államnak előírnak bizonyos jogsértés-megelőzési kötelezettséget. Az első

34 A Nemzetközi Bíróság gyakorlatából pl.: Barcelona Traction, Light and Power Company, Limited (Belgium v. Spain) (New Application: 1962), ICJ, Judgment of 5 February 1970, Second Phase, para. 33-34; East Timor (Portugal v. Australia), Judgment, I.C.J. Reports 1995, para. 29; Legality of the Threat or Use of Nuclear Weapons, Advisory Opinion, I.C.J. Reports 1996, para. 83; Application of the Convention on the Prevention and Punishment of the Crime of Genocide, Preliminary Objections, Judgment, I.C.J. Reports 1996, paras. 31-32.

35 Draft Articles on the Law of Treaties with commentaries, Yearbook of the International Law Commission, 1966, vol. II. 248; Draft Articles on Responsibility of States for Internationally Wrongful Acts with commentaries, Yearbook of the International Law Commission, 2001, vol. II, Part Two, 33, 85, 110-113.

36 Draft Articles on Responsibility of States for Internationally Wrongful Acts with commentaries, Yearbook of the International Law Commission, 2001, vol. II, Part Two. 127.

37 Uo. 41. cikk.

38 Uo. 48. cikk.

39 Uo. 50. cikk (1). 
pillérnél ismertetett megelőzési kötelezettség nem csak arra az államra vonatkozik, amelynek a területén kialakulhat a népirtás. A népirtás tilalmáról szóló 1948. évi egyezmény 1. cikkének és előkészítő anyagainak megfogalmazása azt támasztja alá, hogy annak a megelőzése, megállítása és megbüntetése minden (részes) állam kötelessége. A többi állam fellépése ezekkel a súlyos nemzetközi jogsértésekkel szemben tehát nemzetközi szerződésen (és valószínűleg szokásjogon is) alapul.

Összességében a harmadik pillér jogi alapjainak vizsgálatakor világosan látszik, hogy az államok számos hátrányos intézkedéssel késztethetik az államot a jogsértés abbahagyására, kivéve a fegyveres erőszak alkalmazását (ezt csak a BT rendelheti el). A már folyó jogsértés megakadályozása mellett az államokat megelőzési és megbüntetési kötelezettség is terheli. A megelőzési kötelezettség kontúrjai már az első pillérnél láthatóak voltak. Véleményem szerint azonban az eddigi állami gyakorlatban a megelőzés inkább csak a diplomáciai kapcsolatok és nemzetközi szervezetek határozatai keretén belül maradt. A konkrét beavatkozásra ritkán került sor, már csak akkor, ha a jogsértés megkezdődött. A jogsértésért való felelősségre vonás tekintetében is elfogadott az univerzális joghatóság elmélete, a gyakorlatban azonban nehézkes a müködése. Az ilyen súlyos nemzetközi jogsértések felelősségre vonása hatékonyabban müködik a nemzetközi bírói fórumokon, mint az univerzális joghatóság alapján. A felelősségre vonást és az univerzális joghatóság gyakorlását jelentősen megkönnyítené, ha az aut dedere aut judicare (megbüntetni vagy kiadni) elv is világszinten elfogadott lenne, azonban még nem tartunk itt. ${ }^{40}$

\section{Következtetések}

A koncepcióra az ENSZ több szerve is hivatkozott, így a Biztonsági Tanács például Dárfúrral, ${ }^{41}$ Líbiával| $^{42}$ és Jemennel ${ }^{43}$ kapcsolatos határozataiban, a Közgyülés a szíriai helyzettel összefüggésben, ${ }^{44}$ valamint az Emberi Jogi Tanács is több alkalommal. ${ }^{45}$

Az ENSZ-szervek, különösen a BT hivatkozásai inkább azt támasztják alá, hogy ezek a kötelezettségek már eddig is léteztek, mint hogy egy új szokásjog indult volna el a védelmi felelősséggel. A koncepció egyes pilléreinek alkalmazása, eszközei nem jelentenek újdonságot a korábbi állami kötelezettségek és a nemzetközi közösség cselekvési lehetőségeire tekintettel. Az ENSZ Alapokmány 2. cikk (7) bekezdésében

40 Lásd pl.: Survey of multilateral conventions which may be of relevance for the Commission's work on the topic "The obligation to extradite or prosecute (aut dedere aut judicare)": Study of the U. N. Secretariat. U.N. Doc. No. A/CN.4/630 (2010). 76-78. o.; Preliminary Report on the obligation to extradite or prosecute ("aut dedere aut judicare") by Mr. Zdzislaw Galicki, Special Rapporteur, U.N. Doc. No. A/CN.4/571 (2006), 12-13.

41 S/RES/1674 (2006) Protection of civilians in armed conflict. Ebben a határozatban a BT a 2005. évi csúcstalálkozó eredményeit magában foglaló, A/60/1 (2005) számú ENSZ-közgyűlési határozat 138-139. pontjaira hivatkozik.

42 S/RES/1970 (2011) Peace and security in Africa; S/RES/1973 (2011) Libya, S/RES/2040 (2012) Libya.

43 S/RES/2014 (2011) Middle East.

44 A/RES/66/176 (2011) Situation of human rights in the Syrian Arab Republic, A/RES/66/253 (2012) The situation in the Syrian Arab Republic.

45 Pl.: S-15/1 (Líbia), S-16/1, S-18/1, S-19/1 (Szíria). 
foglalt beavatkozás tilalma ellenére eddig sem volt akadálya annak, hogy ilyen súlyos cselekmények esetén a nemzetközi közösség cselekedjen (lásd az ENSZAlapokmány VI., VII., VIII. fejezetét), mivel ezek a bűncselekmények veszélyeztetik a nemzetközi békét és biztonságot. Ráadásul a szuverenitás és a beavatkozás tilalma nem zárhatja ki a felelősséget a nemzetközi jog megsértéséért.

Elterjedt nézet, hogy a koncepció mögött olyan „hátsó szándék” bújik meg, ami modern kori gyarmatosításra emlékeztet, mivel lehetőséget ad a nagyhatalmaknak a beavatkozásra. Véleményem szerint ez semmilyen ENSZ-dokumentumból nem következik, ráadásul nem is igaz, mivel a korábbiakban bemutatott jogi háttér alapján egyértelmü, hogy az államok évtizedek óta kötelesek nem elkövetni és megakadályozni az ilyen bủncselekményeket. A hivatkozott ENSZ-dokumentumok azt sem támasztják alá, hogy a védelmi felelősség koncepciójára hivatkozva elfogadott lenne a BT-felhatalmazás nélküli fegyveres erőszak alkalmazása.

A súlyos nemzetközi jogsértések megállításának kötelezettsége és az elkövetők felelősségre vonásának elve évtizedek óta univerzálisnak tekinthető, még akkor is, ha a megvalósításban sok hiányosságot láttunk. A koncepcióhoz kapcsolható kötelezettségek közül a megelőzés tűnik a legkevésbé kiforrottnak. Szerződéses magyarázat alig található, a nemzetközi bírósági értelmezés is csekély. A nagyhatalmak megelőzéssel összefüggő magatartása változatos, véleményem szerint a mai napig vannak olyan államok (pl. Kína), amelyek szerint az a más állam belügyeibe való beavatkozást jelentene. A megelőzési kötelezettség nem mindegyik, a védelmi felelősségi koncepcióban szereplő büncselekmény esetében nyugszik szerződéses alapon, a szokásjog univerzalitásának jellege pedig megkérdőjelezhető. Természetesen az erkölcs azt diktálja, hogy ezen, a nemzetközi közösség egészének ártó cselekmények ellen minden állam fellépjen, azonban jelentős különbségek vannak az államok lehetőségei, képességei között. Egy kisebb, távoli ország részéről lehet, hogy az aggodalmat kifejező diplomáciai levelet is elegendőnek tekinthetünk, míg a BT állandó tagjaitól elvárjuk akár a fegyveres akciót is. Ez viszont nem feltétlenül van pozitív hatással a koncepcióra, mivel a harmadik államok kötelezettsége kiszámíthatatlanná válik.

A védelmi felelősség propagandája segíthet tudatosítani az államok nemzetközi jogi kötelességét. Az élénk szakirodalmi és közbeszédi diskurzus befolyásolhatja a norma univerzálissá válását, elősegítheti a megelőzést és felelősségre vonást. Ahhoz azonban, hogy ez a nemzetközi jogban is értékelhető legyen (és ne csak a nemzetközi politikában), mindenképpen szükség van a norma tartalmának egyértelmüsítésére és tisztázására.

\section{Abstract}

The concept of the responsibility to protect has emerged in the practice of the United Nations in the past years, inducing much criticism in the literature. The aim of the author was to present the concept in Hungarian and to analyze it from international legal point of view. According to the author the concept is just a paraphrased 
principle, responsibility has already existed under the relevant norms of international law. Nevertheless, the content of the obligation and responsibility is not fully clear, especially with respect to the exact meaning of prevention. 